\title{
The composition of settling particles in Lake Zürich
}

\author{
By Rudolf Giovanoli1) Rudolf Brütsch'), Dieter Diem²) Gertrud Osman-Sigg ${ }^{2}$ ) and \\ Laura Sigg ${ }^{2}$ ) \\ 1) Laboratory for Electron Microscopy, University of Bern \\ 2) Institute for Aquatic Sciences, Swiss Federal Institute of Technology, Zürich
}

Manuscript received on 16 January 1980

\begin{abstract}
Settling particles in the Lake Zürich were collected at different depths. Water samples and particles have been analyzed for heavy metals and for organic matter elements. Samples were investigated by transmission electron microscopy, scanning electron microscopy, energy dispersive $\mathrm{X}$ ray and $\mathrm{X}$ ray. The elemental composition of the settling particles was found to be almost constant. Special remarks are made on iron and phosphate and on manganese. Manganese oxidizing microorganisms were found near the bottom of the lake.
\end{abstract}

\section{Introduction}

A hydrodynamic project [1] provided in summer 1978 a convenient infrastructure to suspend at the deepest point of Lake Zürich sediment pans. The authors carried out a small group project in order to assess the settling of suspended matter and the chemistry of the involved minerals in Lake Zürich, using electron microscopy and $\mathrm{X}$-ray diffraction. We briefly summarize some results on the composition of the sediments and the chemical and mineral nature of some of the sediment particles, and report in particular on a manganese(II) oxidizing microorganism.

\section{Experimental}

At the deepest point in Lake Zürich (National Grid Reference coordinate: 687.200/ 238.425), four sediment pans having the dimensions as described by Bloesch [2], at a depth of $9,82,123$ and $133 \mathrm{~m}$, respectively, collected sediments during the two twoweek periods from 22 August to 22 September 1978. Samples were freeze-dried and stored away for investigation. Smaller particles were investigated in a Hitachi HU$12 \mathrm{~A}$ electron microscope using a scanning attachment $\mathrm{H}-5010$ and an energy dispersive X-ray spectrometer Kevex 5100. 
Samples were X-rayed in a Guinier-de Wolff camera with $\mathrm{CuK}_{a}$ and/or $\mathrm{FeK}_{a}$ radiation.

Analyses of some of the elements were made by atomic adsorption spectroscopy. C and $\mathrm{N}$ were analyzed by a $\mathrm{F} \& \mathrm{M}$ Carbon Hydrogen Nitrogen Analyzer Model 185.

\section{Results and discussion}

\section{Composition of sedimenting particles}

Table 1 gives the composition and sedimentation rate of the settling particles. The elemental composition is surprisingly constant. The approximate equation

$$
\begin{aligned}
& 106 \mathrm{CO}_{2}+16 \mathrm{NH}_{4}^{+}+\mathrm{HPO}_{4}^{2-}+106 \mathrm{H}_{2} \mathrm{O} \\
& \text { Photosynthesis } \downarrow \uparrow \text { Respiration } \\
& \underbrace{\left\{\left(\mathrm{CH}_{2} \mathrm{O}\right)_{106}\left(\mathrm{NH}_{3}\right)_{16}\left(\mathrm{H}_{3} \mathrm{PO}_{4}\right)_{1}\right\}}_{\text {Bulk plankton composition }}+106 \mathrm{O}_{2}+14 \mathrm{H}^{+}
\end{aligned}
$$

by Stumm and Morgan [3], Redfield et al. [4] has been suggested to describe the stoichiometry of bulk plankton formation and decomposition. The data in table 1 suggest an approximate composition $\left.{ }^{1}\right)$ of $\left\{\left(\mathrm{CH}_{2} \mathrm{O}\right)_{114}\left(\mathrm{NH}_{3}\right)_{16}\left(\mathrm{H}_{3} \mathrm{PO}_{4}\right)\right\}$. This compares with the plankton composition of $\left\{\left(\mathrm{CH}_{2} \mathrm{O}\right)_{87}\left(\mathrm{NH}_{3}\right)_{17}\left(\mathrm{H}_{3} \mathrm{PO}_{4}\right)_{1}\right\}$ in Lake Biel as reported by Santschi [5].

As table 1 shows, a significant component of the settling material is $\mathrm{CaCO}_{3}$. The latter is precipitated as a result of photosynthesis in the epilimnion and partly dissolved by $\mathrm{CO}_{2}$ resulting from respiration:

$$
\mathrm{Ca}^{2+}+2 \mathrm{HCO}_{3}^{-} \underset{\text { Respiration }}{\stackrel{\text { Photosynthesis }}{\rightleftarrows}} \mathrm{CaCO}_{3}(\mathrm{~s})+\mathrm{H}_{2} \mathrm{O}+\mathrm{CO}_{2} \text {. }
$$

Equation 2 may be added to equation 1 to give

$$
\begin{aligned}
& 106 \mathrm{Ca}^{2+}+212 \mathrm{HCO}_{3}^{-}+16 \mathrm{NH}_{4}^{+}+\mathrm{HPO}_{4}^{2-} \underset{\text { Respiration }}{\stackrel{\text { Photosynthesis }}{\rightleftarrows}} \\
& \left\{\left(\mathrm{CaCO}_{3}\right)_{106}\left(\mathrm{CH}_{2} \mathrm{O}\right)_{106}\left(\mathrm{NH}_{3}\right)_{16}\left(\mathrm{H}_{3} \mathrm{PO}_{4}\right)_{1}\right\}+106 \mathrm{O}_{2}+14 \mathrm{H}^{+} .
\end{aligned}
$$

This composition of biogenically produced particles is not very different from that reported in table 1: $\left\{\left(\mathrm{CaCO}_{3}\right)_{108}\left(\mathrm{MgCO}_{3}\right)_{4}\left(\mathrm{CH}_{2} \mathrm{O}\right)_{114}\left(\mathrm{NH}_{3}\right)_{16}\left(\mathrm{H}_{3} \mathrm{PO}_{4}\right)_{1}\right\}$. This stoichiometric formula accounts for ca. $75 \%$ of the dry weight $\left.{ }^{2}\right)$. The remainder is mostly $\mathrm{SiO}_{2}$ and some aluminum silicate (kaolinite); thus the formula may be

1) In computing this average the composition of the particles in the epilimnion was disregarded.

2) Biogenically produced $\mathrm{CaCO}_{3}$ (calcite) in fresh water is mostly precipitated from the water and is thus usually not a component of the algae. 
Table 1. Elemental composition and sedimentation rate of settling particles.

\begin{tabular}{|c|c|c|c|c|c|c|c|c|c|c|c|c|c|c|}
\hline \multirow[t]{2}{*}{ Date } & \multirow[t]{2}{*}{ No. } & \multirow[t]{2}{*}{ Depth (m) } & \multirow{2}{*}{$\begin{array}{l}\text { Settling rate }{ }^{1} \text { ) } \\
\text { g freeze-dried } \\
\text { suspended solids } \\
\text { per } \mathbf{m}^{2} \text { per day }\end{array}$} & \multicolumn{11}{|c|}{ Moles per $g$ freeze-dried suspended solids } \\
\hline & & & & $\times 10^{3}$ & $\times 10^{3}$ & $\times 10^{3}$ & $\times 10^{3}$ & $\times 10^{6}$ & $\times 10^{6}$ & $\times 10^{6}$ & $\times 10^{6}$ & $\times 10^{6}$ & $\dot{x} 10^{\circ}$ & $\times 10^{9}$ \\
\hline \multirow[t]{4}{*}{22 August to 5 September } & la & 9 & 3.2 & 5.9 & 0.11 & 6.0 & 0.85 & 31 & 63 & 3 & 1.7 & 0.34 & 33 & 3.0 \\
\hline & $2 a$ & 82 & 2.6 & 5.9 & 0.19 & 6.2 & 0.81 & 47 & 134 & 21 & 2.3 & 0.42 & 20 & 1.4 \\
\hline & $3 a$ & $\left.123^{2}\right)$ & 2.4 & 5.2 & 0.22 & 6.5 & 0.98 & 58 & 170 & 130 & 3.2 & 0.47 & 52 & 0.8 \\
\hline & $4 a$ & 133 & 2.5 & 5.3 & 0.24 & 6.2 & 0.82 & 52 & 170 & 300 & 3.6 & 0.61 & 53 & 3.3 \\
\hline \multirow[t]{4}{*}{5 to 22 September 1978} & $1 b$ & $-3)$ & & & & & & & & & & & & \\
\hline & $2 b$ & 82 & 2.3 & 5.1 & 0.15 & 6.2 & 0.86 & 27 & 100 & 20 & 2.7 & 0.34 & 35 & 1.4 \\
\hline & $3 b$ & $\left.123^{4}\right)$ & 1.3 & 5.6 & 0.22 & 6.0 & 0.89 & 52 & 130 & 50 & 2.9 & 0.41 & 39 & 1.2 \\
\hline & $4 b$ & 133 & 1.4 & 5.4 & 0.26 & 5.0 & 0.57 & 41 & 170 & 190 & 5.3 & 0.81 & 52 & 3.7 \\
\hline
\end{tabular}

1) Calculated merely on the basis of the geometry of the sediment pans and neglecting dissolution and mineralization during the 14-day collection.

2) Mean of two samples.

3) The sample at $9 \mathrm{~m}$ was lost.

4) Two samples were taken for each point, but the results of one sample only are given. 


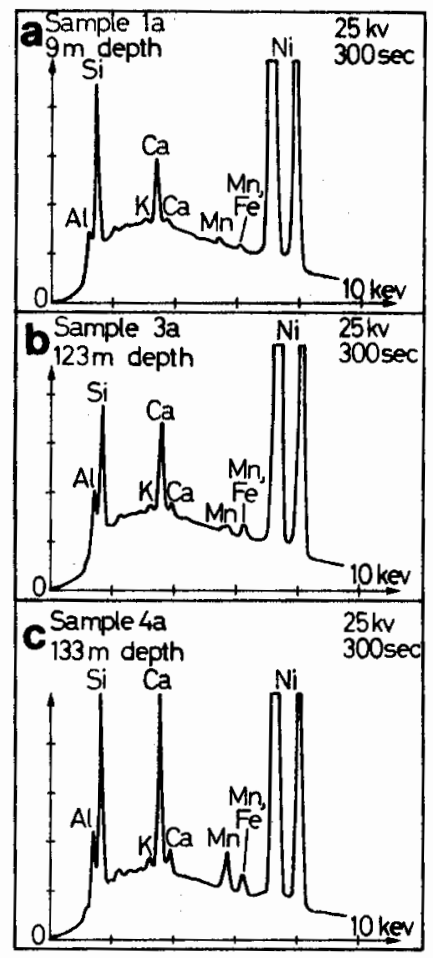

Figures 1 a-c. Micro X-ray fluorescence spectra of the sediment samples collected at various depths. The $\mathrm{Mn}$ and $\mathrm{Fe}$ contents increase in the deeper samples while $\mathrm{Si}$ relative to $\mathrm{Al}$ and $\mathrm{Ca}$ decrease.

enlarged to include $\left(\mathrm{SiO}_{2}\right)_{4}$. It is difficult to draw definite conclusions on the planktonic composition and its variation with time and depth from such a limited number of samples; furthermore, sedimenting particles collected at the same time at various depths have been biosynthesized at different times. It is nevertheless tempting to hypothesize that equation 3 provides a stoichiometric explanation for the observation that the elemental composition of the particles remains relatively constant upon partial dissolution (microbial mineralization and concomitant dissolution by $\mathrm{CO}_{2}$ ) of the biogenic debris. This hypothesis finds some additional support by the observation that correlations in the hypolimnetic concentrations of nitrate, phosphate and oxygen are observed in Lake Zürich [3].

It is also interesting to note that the heavy metals $\mathrm{Fe}, \mathrm{Zn}, \mathrm{Cu}, \mathrm{Pb}$ and $\mathrm{Cd}$ (as opposed to $\mathrm{Mn}$ ) show relatively little variation in their proportional abundance, especially if one disregards the samples taken at the smallest and at the largest depth. Some of these elements, especially $\mathrm{Mn}$, are present at higher concentrations in the samples of a depth of $133 \mathrm{~m}$ ( $1 \mathrm{~m}$ above the sediment-water interface).

The micro X-ray fluorescence spectra (fig. 1) of representative samples show that the $\mathrm{Mn}$ and $\mathrm{Fe}$ contents increase markedly while Si relative to $\mathrm{Al}$ and $\mathrm{Ca}$ decreases in the deeper samples. 
Table 2 .

\begin{tabular}{|c|c|c|c|c|c|c|c|c|c|c|c|c|c|c|c|c|}
\hline \multirow[t]{2}{*}{ Date } & \multirow[t]{2}{*}{ No. } & \multirow[t]{2}{*}{$\begin{array}{l}\text { Depth } \\
\text { (m) }\end{array}$} & \multirow{2}{*}{$\begin{array}{l}\mathrm{Ca} \\
\times 10^{3} \\
\end{array}$} & \multirow{2}{*}{$\begin{array}{l}\mathrm{Mg} \\
\text { Metals } \\
\times 10^{6}\end{array}$} & \multirow{2}{*}{$\begin{array}{l}\mathrm{Fe} \\
\text { total in } \\
\times 10^{9}\end{array}$} & \multirow{2}{*}{$\begin{array}{l}\mathrm{Mn} \\
\text { moles } \\
\times 10^{9} \\
\end{array}$} & \multirow{2}{*}{$\begin{array}{l}\text { Zn } \\
\text { per } 1 \\
\times 10^{9} \\
\end{array}$} & \multirow{2}{*}{$\begin{array}{l}\mathrm{Cu} \\
\times 10^{9} \\
\end{array}$} & \multirow{2}{*}{$\begin{array}{l}\mathrm{Pb} \\
\times 10^{9} \\
\end{array}$} & \multirow{2}{*}{$\begin{array}{l}\mathrm{Cd} \\
\times 10^{9} \\
\end{array}$} & \multirow{2}{*}{$\begin{array}{l}\mathrm{DOC}^{1} \text { ) } \\
\times 10^{6} \\
\end{array}$} & \multirow{3}{*}{$\begin{array}{l}\left.\left.\text { o-PO } \mathrm{P}_{4}-\mathrm{P}^{\mathrm{l}}\right)^{2}\right) \\
\text { Moles } \\
\text { per } 1 \\
\times 10^{6} \\
0.065\end{array}$} & \multirow{2}{*}{$\begin{array}{l}\text { Alk } \\
\text { Moles } \\
\text { per } 1 \\
\times 10^{3} \\
\end{array}$} & \multirow[t]{2}{*}{$\left.\mathrm{pH}^{2}\right)$} & \multirow{2}{*}{$\begin{array}{l}\mathrm{CO}_{2}^{2} \text { ) } \\
\mathrm{Moles} \\
\text { per } 1 \\
\times 10^{6} \\
\end{array}$} & \multirow{2}{*}{$\begin{array}{l}\mathrm{NO}_{3}-\mathrm{N}^{2} \text { ) } \\
\text { Moles } \\
\text { per 1 } \\
\times 10^{6} \\
\end{array}$} \\
\hline & & & & & & & & & & & & & & & & \\
\hline \multirow[t]{7}{*}{5 to 22 Sept. 1978} & la & 10 & 1.02 & 218 & 720 & 18 & 110 & 6.3 & $<1$ & $<1$ & 130 & & 2.30 & 8.0 & 75 & 28.6 \\
\hline & $2 \mathrm{a}$ & 85 & 1.12 & 243 & 1,100 & 55 & 15 & 16 & $<1$ & $<1$ & 110 & 2.1 & 2.51 & 7.7 & 132 & 55.4 \\
\hline & $3 a$ & 125 & 1.07 & 243 & $<360$ & 180 & 46 & 13 & $<1$ & $<1$ & 120 & 2.9 & 2.54 & 7.5 & 227 & 57.1 \\
\hline & ib & 10 & 0.92 & 226 & 900 & 18 & 15 & 7.9 & $<1$ & $<1$ & 120 & 0.03 & 2.19 & 8.1 & 43 & 25.4 \\
\hline & $2 \mathrm{~b}$ & 46 & 1.15 & 247 & $<360$ & 55 & 61 & 9.4 & $<1$ & $<1$ & 100 & 2.0 & 2.55 & 7.7 & 136 & 55.7 \\
\hline & $3 b$ & 120 & 1.12 & 247 & $<360$ & 310 & 31 & 6.3 & $<1$ & $<1$ & 140 & 2.7 & 2.55 & 7.6 & 198 & 59.3 \\
\hline & $4 b$ & 133 & 1.12 & 247 & $<360$ & 2,900 & 110 & 9.4 & $<1$ & $<1$ & 110 & 3.6 & 2.57 & 7.5 & 261 & 49 \\
\hline
\end{tabular}

1) Filtered $0.45 \mu \mathrm{m}$.

2) Samples taken by Zimmermann [6] at the dates 4 September and 4 October, respectively. 


\section{Water composition}

The lake water composition has been regularly analyzed for many years by Zimmermann [6]. Table 2 gives the mean composition of the major inorganic constituents. Concentration depth profiles of alkalinity, $\mathrm{Ca}^{2+}, \mathrm{pH}, \mathrm{CO}_{2}, \mathrm{NO}_{3}^{-}, \mathrm{HPO}_{4}^{2-}$ and of $\mathrm{O}_{2}$ illustrate that some of the biogenic particles synthesized in the epilimnion become mineralized and dissolved in the hypolimnion, e.g. $\left[\mathrm{Ca}^{2+}\right]$ increases from $0.95 \times 10^{-3} \mathrm{M}$ to $1.12 \times 10^{-3} \mathrm{M}$; [Alk] increases correspondingly from $2.2 \times 10^{-3} \mathrm{Eq} /$ 1 to $2.55 \times 10^{-3} \mathrm{Eq} / 1$. The profile for dissolved oxygen is given in figure 7 ; near the bottom, phosphates reach values as high as $100 \mu \mathrm{g}$ P per liter. Soluble manganese, i.e. $\mathrm{Mn}^{2+}$, is not detected until a depth of $123 \mathrm{~m}(=0.02 \mathrm{mg} / \mathrm{l})$. Its concentration increases to $0.15 \mathrm{mg} / \mathrm{l}$, immediately above the sediments. Obviously $\mathrm{Mn}^{2+}$ is released to the overlying water from the sediments. The concentration of soluble iron, i.e. $\mathrm{Fe}^{2+}$, remains below $0.02 \mathrm{mg} / 1$ for the entire water column.

\section{Mineral phases}

$\mathrm{X}$-ray diffraction showed calcite $\mathrm{CaCO}_{3}$ and quartz $\alpha-\mathrm{SiO}_{2}$ as main phases in all samples. In the electron microscope it was possible to identify clay mineral platelets. Selected area diffraction gives typical clay mineral patterns which we attribute to kaolinite.

The iron bearing phase has neither produced X-ray reflections nor an electron diffraction. Particles of the shape of common oxide hydroxides (goethite $a$-FeOOH and others) could not be found in the electron micrographs. The line intensity ratio $\mathrm{FeK}_{\alpha} / \mathrm{PK}_{a}$ in the X-ray fluorescence spectrum produced in the electron microscope did not correspond to known iron phosphates which were used for reference.

Manganese has been found in the two deepest sediment pans in a microorganism (fig. 2-4). The formal oxidation state of the $\mathrm{Mn}$ in the incrustations of these microorganisms was found to correspond to $\mathrm{Mn} \mathrm{O} \approx 1.6$.

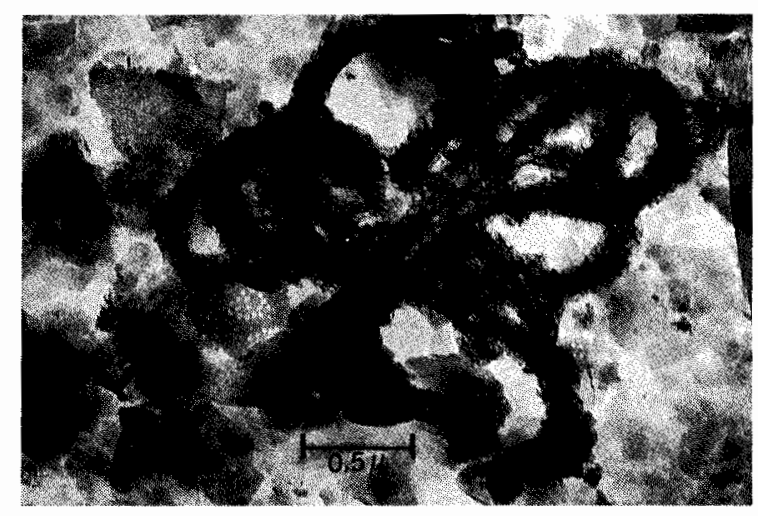

Figure 2. Electron micrograph of manganese microorganisms in sample $4 \mathrm{a}$ (133 m depth). $\times 36,000$. 

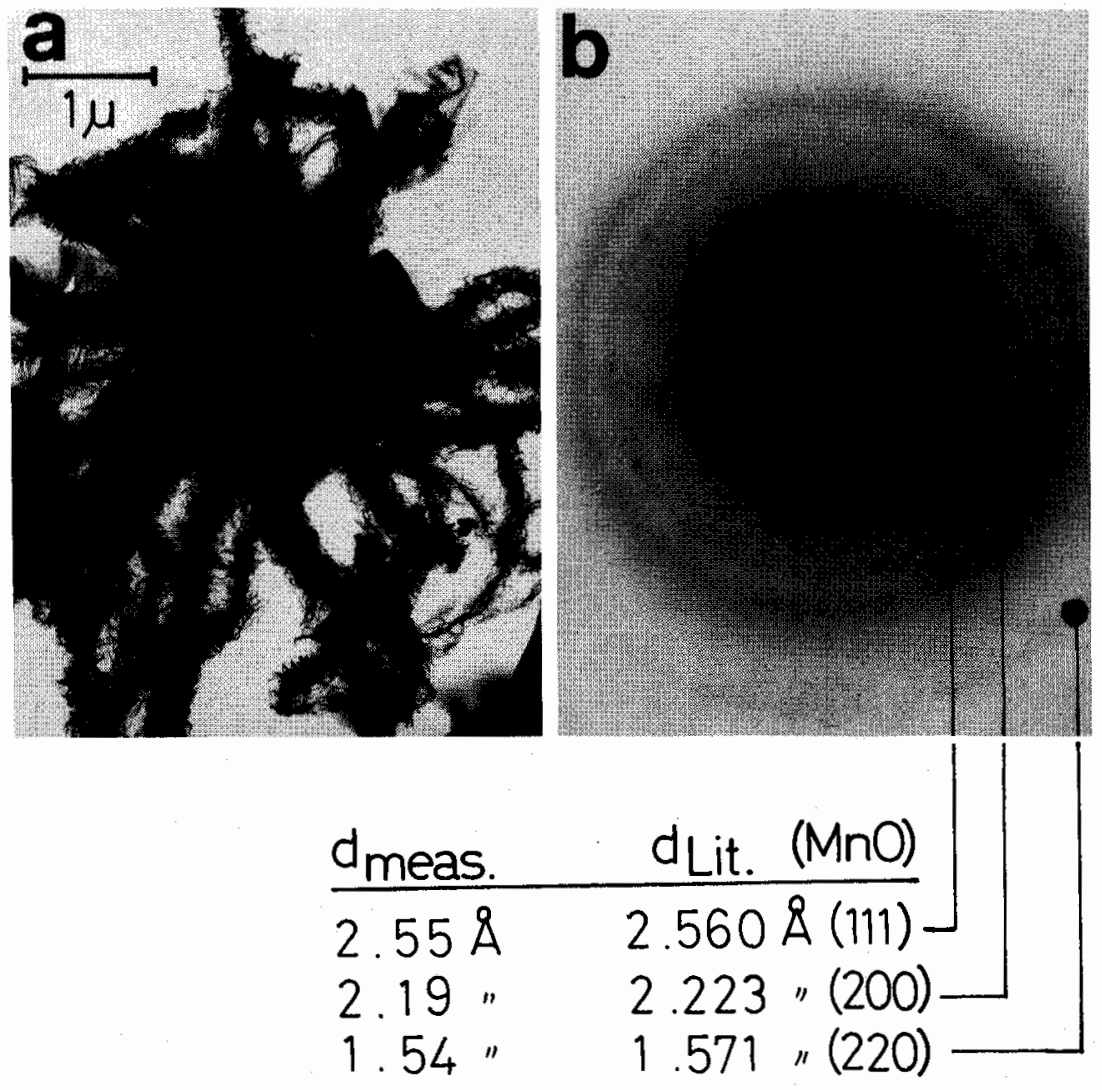

Figures $3 a$ and $b$. Electron micrograph of manganese microorganisms in sample $4 a(a), \times 10,000$, and its electron diffraction (b) which is typic for $\mathrm{MnO} . \gamma-\mathrm{MnOOH}$ is easily reduced to $\mathrm{MnO}$ by the e beam especially in presence of organic matter.

\section{Iron(III) and phosphate}

Oxides and oxide hydroxides of iron(III) are believed to be important sinks for phosphate. It has been estimated [7] on the basis of laboratory experiments that the surface sites of $a$-FeOOH goethite $\left(10^{-6}\right.$ moles $\left.1^{-1}\right)$ exposed to lake water $\left(\mathrm{P}_{\mathrm{T}}=\right.$ $10^{-6} \mathrm{M}, \mathrm{pH}=7.5$ ) will be preponderantly occupied by phosphate. An iron(III) phosphate mineral such as strengite cannot be formed under these conditions. No particle with a diameter larger than $500 \AA$ were found that could consist of an iron compound. $\mathrm{Fe}$ is ubiquitously present but - as shown by $\mathrm{X}$ rays of iron - not fully homogeneously distributed throughout the sample; individual particles containing an iron content somewhat higher than the mean content are usually clays. Figure 5 gives an example. Most likely iron(III) is present as amorphous $\mathrm{FeOOH} \cdot \mathrm{xH}_{2} \mathrm{O}$ forming thin coatings. This material is characterized by large specific surface areas and capable of specifically adsorbing phosphates. The settling mass transport of $\mathrm{Fe}$ and $P$ is in the order of $0.2-0.4$ mmoles $\mathrm{Fe} \mathrm{m}^{-2}$ day ${ }^{-1}$ and $0.06-0.15$ mmoles $\mathrm{P} \mathrm{m}^{-2}$ 

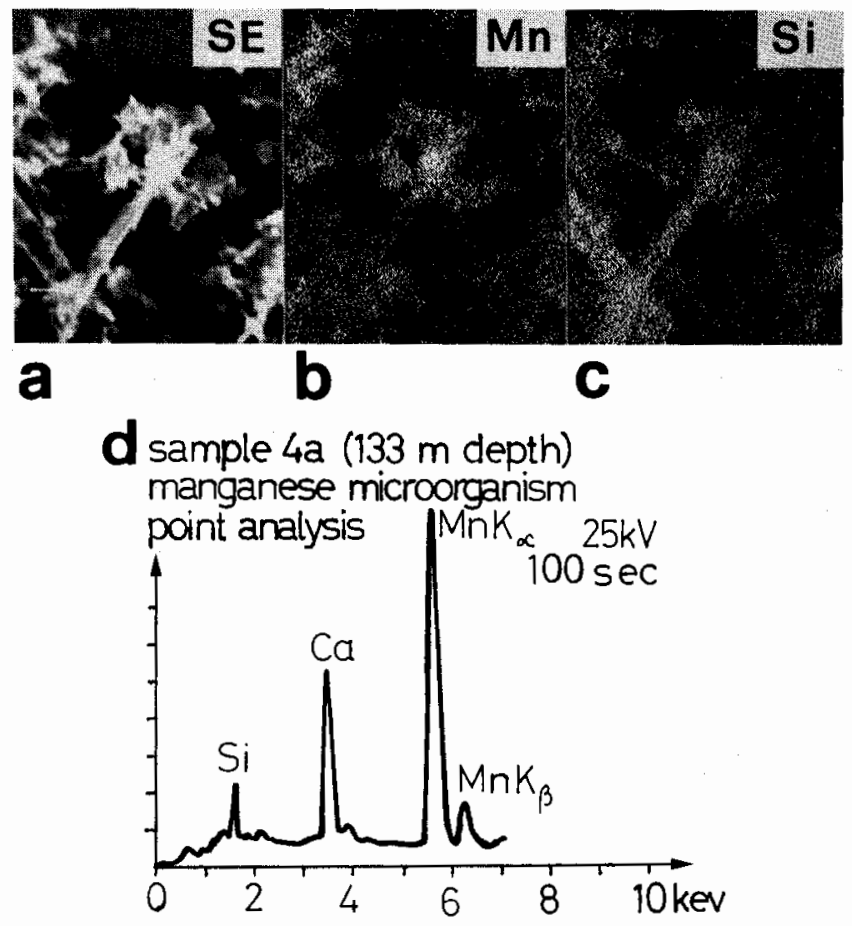

Figures 4a-d. Manganese microorganisms and diatoms in sample a: Scanning electron micrograph, $\times 1,400$ (secondary electron image); $\mathrm{b}$ : same section in the light of $\mathrm{Mn}$ radiation; $\mathrm{c}$ : same section in the light of Si radiation; d: X-ray fluorescence spectrum of the manganese microorganism (point analysis).

day $^{-1}$, respectively; the $\mathrm{Fe} / \mathrm{P}$ atomic ratio is ca. 3 . If most $\mathrm{Fe}$ available in the settling particles were present as $\mathrm{FeOOH} \cdot \mathrm{xH}_{2} \mathrm{O}, 30 \%$ of the $\mathrm{P}$ at best could be bound to the iron(III). It thus appears, at least for the period of observation, that the transport of iron(III) did not serve as an important conveyor of phosphate. In the top layers of the sediments which reflect a more integral condition than our samples the $\mathrm{Fe} / \mathrm{P}$ atomic relationship is ca. 10-15. One also has to consider that the P-loading of Lake Zürich has increased by more than one order of magnitude in the last 30 years, while the iron load most likely did not increase to a similar extent. Analysis of the first $60 \mathrm{~cm}$ of the sediments [9] show a good correlation between oxalate extractable iron and oxalate extractable phosphate (fig.6). This correlation reflects most likely the adsorption of phosphate by iron(III) hydroxides.

\section{Manganese microorganisms}

The occurrence of manganese bacteria in Lake Zürich has been reported before by Minder [10] and by Pavoni [11]. Minder describes Mn-bacteria, in the form of a starlike organism of ca. $10 \mu \mathrm{m}$ diameter, as typical for water samples of depths of 120 and $130 \mathrm{~m}$. The higher valent $\mathrm{Mn}$ is deposited in the sheaths of this organism. 


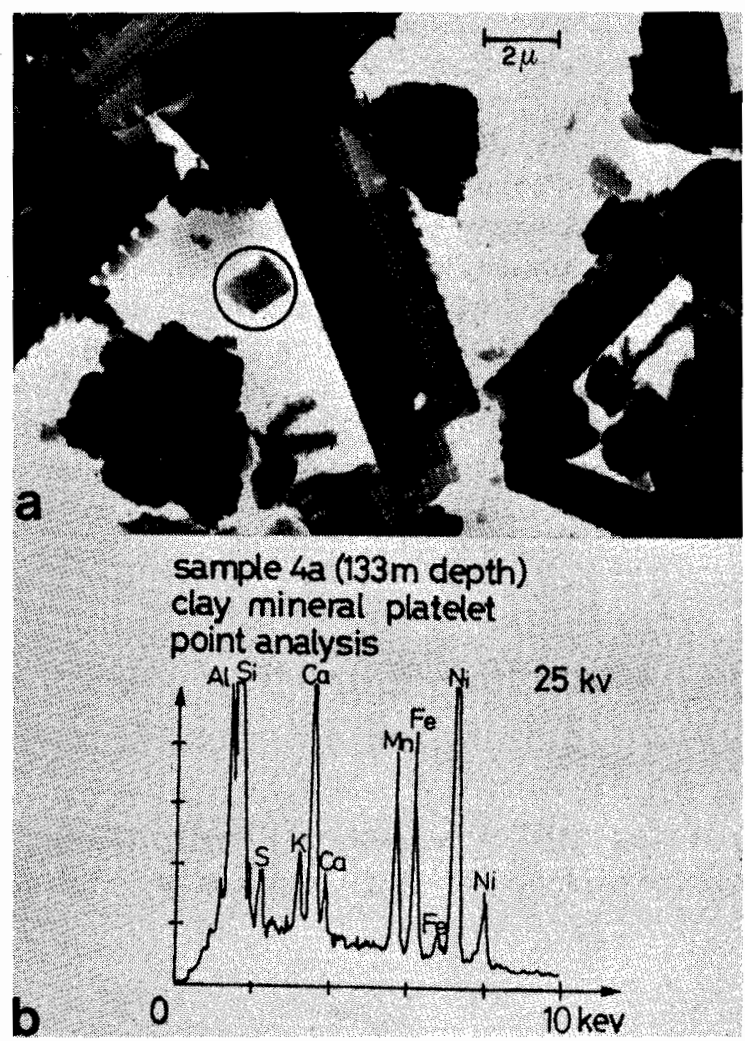

Figures $5 \mathrm{a}$ and $\mathrm{b}$. a: Electron micrograph of sample $4 \mathrm{a} . \times 6,000$. b: Micro X-ray fluorescence spectrum of the clay mineral platelet in the center of figure $5 \mathrm{a}$ (point analysis). The lines of $\mathrm{Fe}$ (and also of $\mathrm{Mn}$ ) are more intense compared to the overall spectrum of figure le.

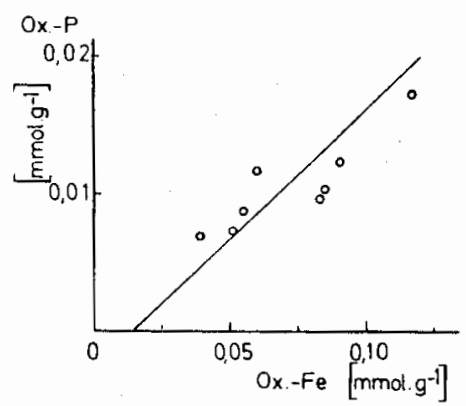

Figure 6. Oxalate-extractable Fe- and P-contents of sediments from Lake Zürich. Data by Schär [9]. 
According to Pavoni, the concentration of the organisms in near sediment samples may be as high as a few million per $\mathrm{cm}^{3}$.

According to the descriptions, the organism found in our sample is identical to the organisms described by Minder and Pavoni and those observed in the Wahnbach $[12,13]$. Clasen, Minder and Pavoni, following a suggestion of Berger [14], classified the organism as Leptothrix echinata, but others refer to the same microorganism as Metallogenium [15, 16]. The present knowledge about ecology, culture and types of manganese oxidizing microorganisms was summarized by Schweisfurth et al. [17].

Typically this $\mathrm{Mn}$ (II) oxidizing microorganism is found mostly a few meters above the sediment-water interface, where the dissolved oxygen concentration becomes reduced to concentrations of $1 \mathrm{mg} \mathrm{O} / 1$ and below (fig.7). Thus, these microorganisms exist in a redox potential gradient. The reducing conditions of the sediments release soluble $\mathrm{Mn}(\mathrm{II})$ to the overlying water. Despite the small $\mathrm{O}_{2}$ concentration, $\mathrm{Mn}(\mathrm{II})$ is here no longer thermodynamically stable as is shown by the following calculation:

$$
\begin{aligned}
& \mathrm{Mn}^{2+}+1 / 4 \mathrm{O}_{2}(\mathrm{~g})+3 / 2 \mathrm{H}_{2} \mathrm{O} \rightleftarrows \mathrm{MnOOH}(\mathrm{s})+2 \mathrm{H}^{+} ; \quad \log \mathrm{K}=-4.5 \\
& \log \left[\mathrm{Mn}^{2+}\right]=4.5-1 / 4 \log \mathrm{P}_{\mathrm{O}_{2}}-2 \mathrm{pH}
\end{aligned}
$$

with $\mathrm{P}_{\mathrm{O}_{2}}=0.02$ atm and $\mathrm{pH}=8, \log \left[\mathrm{Mn}^{2+}\right]=-11.1$. Hence, these organisms mediate, i.e. catalyze the oxidation of $\mathrm{Mn}(\mathrm{II})$, which in their absence is very slow [3, $18]$.

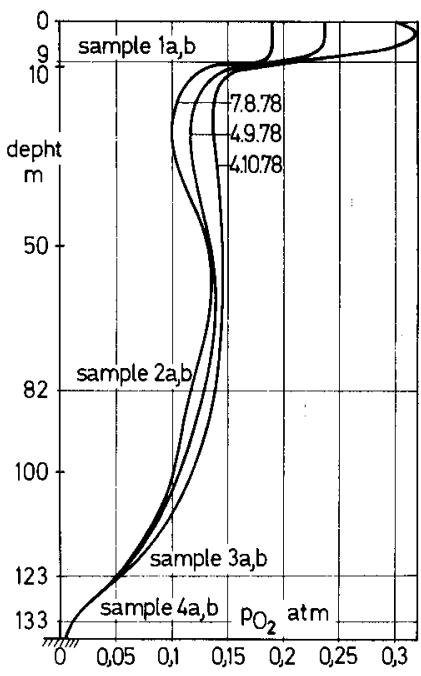

Figure 7. Profile for dissolved oxygen in Lake Zürich measured from August to October 1978 (data by Zimmermann [6]).

3) We infer from the experimentally determined oxidation state that an oxide-hydroxide of trivalent $\mathrm{Mn}$ is formed. The calculation is for $\gamma-\mathrm{MnOOH}$. The same calculation showing similar thermodynamic instability of $\mathrm{Mn}^{2+}$ can also be made for the oxidation to an $\mathrm{Mn}$ (IV) oxide. 


\section{Summary}

Settling material in Lake Zürich has been collected twice at four different depths during a two-week period in late summer 1978. The elemental composition of the material was found to be nearly independent of depth. The stoichiometry was found to be $\left\{\left(\mathrm{SiO}_{2}\right)_{4}\left(\mathrm{CaCO}_{3}\right)_{106} \cdot\left(\mathrm{CH}_{2} \mathrm{O}\right)_{106}\left(\mathrm{NH}_{3}\right)_{16}\left(\mathrm{H}_{3} \mathrm{PO}_{4}\right)_{1}\right\}$. Calcite, quartz and clay minerals were detected by $\mathrm{X}$-ray diffraction. No iron-bearing phase producing $\mathrm{X}$-ray reflections or electron diffraction was found. Nevertheless, iron oxides and iron oxide hydroxides seem to be important sinks for phosphate. Iron(III) is most likely present as amorphous FeOOH. It is capable to adsorb phosphate as shown by a good correlation between oxalate extractable iron and oxalate extractable phosphate in the underlying sediments. Manganese oxidizing microorganisms were found $1 \mathrm{~m}$ above the lake bottom, together with extremely high total concentrations of manganese, both in unfiltered water samples and in the collected sedimented particulate matter. A point analysis by X-ray fluorescence spectrum of the organisms showed a very high $\mathrm{Mn} / \mathrm{Ca}$ ratio.

\section{ZUSAMMENFASSUNG}

Die Zusammensetzung sedimentierender Partikel im Zürichsee

Die chemische und zum Teil auch die mineralogische Zusammensetzung der in Sedimentpfannen während des Sommers 1978 im Zürichsee aufgefangenen sedimentierenden Teilchen wurde bestimmt. Die analytische Zusammensetzung entspricht ungefähr der Formel

$$
\left\{\left(\mathrm{SiO}_{2}\right)_{4}\left(\mathrm{CaCO}_{3}\right)_{106} \cdot\left(\mathrm{CH}_{2} \mathrm{O}\right)_{106}\left(\mathrm{NH}_{3}\right)_{16}\left(\mathrm{H}_{3} \mathrm{PO}_{4}\right)_{1}\right\}
$$

und weist relativ geringe Variation für Proben verschiedener Tiefe auf. Calcit, Quarz und Kaolinit sind in allen Proben vorhanden. Eisen liegt als amorphes $\mathrm{FeOOH} \cdot \mathrm{xH}_{2} \mathrm{O}$ mit grosser spezifischer Oberfläche, das Phosphat chemisch adsorbieren kann, vor. Mangan-Mikroorganismen werden in den sedimentnahen Schichten gefunden; diese oxidieren das aus den Sedimenten herausdiffundierende Mn(II) zu Mn(III)Oxid/Hydroxiden.

\section{RÉSUMÉ}

La composition des particules en suspension du lac de Zurich

La composition chimique et en partie minérale des sédiments qui ont été récoltés au moyen d'un collecteur de sédiments dans le lac de Zurich pendant l'été 1978 ont été analysées. La composition trouvée ressemble à peu près à cette formule:

$$
\left\{\left(\mathrm{SiO}_{2}\right)_{4}\left(\mathrm{CaCO}_{3}\right)_{106} \cdot\left(\mathrm{CH}_{2} \mathrm{O}\right)_{106}\left(\mathrm{NH}_{3}\right)_{16}\left(\mathrm{H}_{3} \mathrm{PO}_{4}\right)_{1}\right\}
$$

et l'on peut considérer que la variation de cette formule pour tous les échantillons a différentes profondeurs est insignifiante. On trouve dans tous les échantillons de la calcite, du quartz et du kaolin. Le fer se trouve à l'état amorphe sous forme de $\mathrm{FeOOH} \cdot \mathrm{xH}_{2} \mathrm{O}$ et sa capacité d'adsorption des phosphates est grande. On a trouvé dans l'eau se trouvant au-dessus des sédiments des microorganismes réalisant l'oxydation du manganèse II en manganèse III soit en oxydes, soit en hydroxydes.

\section{ACKNOWLEDGMENT}

We wish to thank E. Ettinger for deft technical assistance and Werner Stumm for encouragment and aid to our efforts. J. Clasen and U. Hässelbarth were kind enough to provide for comparison purposes 
samples of Mn-microorganisms. We are also indepted to the water pollution control office of the Canton of Zürich and to the water supply authorities of the City of Zurich. Our research on the chemistry of sediment minerals is supported by the Swiss National Foundation.

\section{REFERENCES}

1 Project of the Swiss National Foundation (Grundlegende Probleme des schweizerischen Wasserhaushaltes) on Lake Currents 1978.

2 Bloesch, J.: Schweiz. Z. Hydrol. 36, 71 (1974).

3 Stumm, W., and Morgan, J.J.: Aquatic Chemistry. Wiley-Interscience, New York 1970.

4 Redfield, A.C., Ketchun, B.H., and Richards, F.A., in: Hill, M.N. (ed): The Sea, vol.2. WileyInterscience, New York 1966.

5 Santschi, P.: Doctoral Dissertation, University of Bern 1975.

6 Zimmermann, U.: Personal communication, Zürich.

7 Sigg, L., and Stumm, W.: Colloids and Surfaces 2, 101 (1980).

8 Feitknecht, W., Giovanoli, R., Michaelis, W., and Muller, M.: Helv. chim. Acta 56, 2847 (1973).

9 Schär, G.: EAWAG, unpublished data (1976).

10 Minder, L.: Verh. int. Limnol. 9, 303 (1940).

11 Pavoni, M.: Schweiz. Z. Hydrol. 25, 219 (1963).

12 Clasen, J.: Staddehygiene 7, 171 (1969).

13 Vernet, J.-P.: Personal communication (1978).

14 Berger, H.: Zentbl. Bakt. ParasitKde (II) 92, 401 (1935).

15 Perfiliev B.V., et al.: Applied Capillary Microscopy. Consultants Bureau, New York 1965.

16 Sapozhnikov, D.G., in: Manganese Deposits of the Soviet Union. Izdatel'stvo 'Nanka', Moskva 1967 (translated by Israel Program for Scientific Translating, Jerusalem 1970).

17 Schweisfurth, R., et al.: Vortrag Deutsche Gesellschaft für Biologie, Kiel 1977.

18 Stumm, W., and Giovanoli, R.: Chimia 30, 423 (1976).

Addresses of the authors: R. Giovanoli, R. Brutsch, Laboratory for Electron Microscopy, University of Bern, Sablistrasse 6, Bern, Switzerland - D. Diem, Gertrud Osman-Sigg, Laura Sigg, Institute for Aquatic Sciences, Swiss Federal Institute of Technology, EAWAG, CH-8600 Dübendorf, Switzerland. 